\title{
Factors affecting the use of primary health care clinics for children
}

\author{
F A AKESODE \\ From the Department of Pediatrics, College of Medicine, University of Lagos, Idi-Araba, Lagos, Nigeria
}

SUMMARY Factors affecting the attendance at primary health care clinics in Lagos were studied at Oguntolu Clinic and Randle Road Health Centre among 120 Nigerian children. The level of immunisation was a measure of the frequency (regularity) of attendance at the clinics. Certain socioeconomic, psychological, and demographic factors were the major factors affecting attendance. Among those fully immunised, the family sizes were low, the mothers and fathers were educated, the mothers were younger, and a higher proportion of the children were boys. The family health workers were responsible for earlier and regular attendance at the clinic. The perception of the severity of symptoms of disease was a major psychological factor affecting attendance. A predictive model for the identification of high need but low users and low need but high users is presented to facilitate the formulation of more realistic primary health care programme priorities and policies.

Recent proliferation of private medical clinics and hospitals in major cities and towns reflects growing public concern with the uneven availability and use of health-related resources in Nigeria. Some policy makers assume that poor use of these services by some segments of the population has been due largely to socioeconomic, psychological, demographic, or geographical barriers. Accordingly infant welfare clinics and primary health care centres were built as near as possible to the homes of the people. These centres are experted to produce a dramatic upsurge in use and a corresponding improvement in the general health of the children.

A study of how a neighbourhood health centre was used suggested that neither the cost barriers nor geographical distance alone explained why some families sought health-related services while others remained aloof. ${ }^{1}$ Other studies observed that families least in need of medical care service were the most active consumers while those with the greatest apparent need responded sporadically, minimally, or not at all. ${ }^{2-4}$

The populations served by these infant welfare clinics and public health care centres vary widely in respect of personal and family characteristics and behavioural patterns. Objective indicators are needed to differentiate high risk from low risk and receptive from resistant families sharing services and living in the same catchment area. This study was undertaken to clarify suspected systematic differences between area residents and to suggest practical guidelines to identify and reach every part of the community for whom the primary health care programme is intended.

\section{Materials and method}

Mothers attending infants' primary health care centres with children aged from 10 months to 5 years were studied at two clinics in Lagos. The two clinics selected were the Randle Road Health Centre and the Oguntolu Street Clinic. The Randle Health Centre is organised as the primary health care centre of the Surulere local government while Oguntolu Clinic is run as a primary health centre by the Institute of Child Health and Primary Care of the University of Lagos. The mothers were interviewed and the following points were asked: socioeconomic status of the mother and father, ages of the children, educational status of the mother and father, sex of the child, family size, number of visits made since starting clinic and number of visits missed, and also the number of immunisations received. The immunisations given in these centres include BCG, triple antigen (diphtheria, pertusis, and tetanus), polio, and measles vaccines.

Altogether 120 mothers were interviewed, 60 from each clinic. The mothers were picked randomly by ballot, and when a mother did not want to be interviewed another was selected, also by ballot, to replace her. Mothers were interviewed on clinic days, within clinic hours, and were reassured that the information given would be confidential and would 
not be used for any tax purposes. Consequently, no questions on income were asked.

\section{REGISTRATION AT THE CLINICS}

Both clinics have identified target areas and each serves between 30000 and 50000 people. Registration is usually limited to families residing in the target areas; however, this restriction does not apply to dispensary, maternity, and immunisation services.

At the Oguntolu Clinic the target area is divided into five sections; each section is assigned two family health nurses, two or three field health workers, and one or two field health assistants. Thus the team of health workers are responsible for and know the families of each section. This ideally provides the families with continuity of health care.

The field health workers and assistants refer families to the clinic for registration. After registering, each family is assigned to a family health nurse who sees them whenever they come to the clinic. The field health workers and assistants visit the families in the home, doing health education, helping the family to use the clinic, referring health problems seen in the home, and following up the progress of particular cases seen in the clinic.

The field health workers also conduct surveys to help the clinic staff learn more about the community and to evaluate the work of the clinic.

The Randle Health Centre allocates health visitors and public health nurses to different sections of the target area. These nurses perform home visits but do not go into the community to recruit patients for their centre. So far as possible the nurses at the centre attempt to see the same child on every visit.

\section{SERVICES}

At both clinics any child brought in may receive the following immunisation-BCG, triple antigen, oral polio, and measles vaccines. Health education with emphasis on child spacing and nutrition is given. Family planning services are provided when requested. Food demonstration classes where mothers are taught the best and the most economic ways of preparing well-balanced diet from the local available materials are held twice weekly.

Antenatal care is provided by the midwives, and two doses of tetanus toxoid are given, six weeks apart, to the unimmunised pregnant women during the second trimester. Complicated cases are referred to the obstetricians.

\section{Results}

\section{FAMILY SIZE AND COMPOSITION}

Table 1 shows the family size and the number of children fully or appropriately immunised for their age. At the Oguntolu Clinic there is an average of $3 \cdot 2$ children per family while Randle Clinic has $2 \cdot 8$ children per family.

In those families with one child $88 \%$ of the children were fully or appropriately immunised. The number of children appropriately immunised for their age has an inverse relationship with the number of children in the family.

Table 1 Effect of family size on immunisation

\begin{tabular}{|c|c|c|c|c|c|}
\hline \multirow[b]{2}{*}{ No of children } & \multicolumn{3}{|c|}{ No of respondents } & \multirow[b]{2}{*}{$\begin{array}{l}\text { No of children } \\
\text { fully immunised }\end{array}$} & \multirow[b]{2}{*}{$\begin{array}{l}\text { Percentage } \\
\text { fully immunised }\end{array}$} \\
\hline & $\begin{array}{l}\text { Oguntolu Street } \\
\text { Clinic }\end{array}$ & $\begin{array}{l}\text { Randle Road } \\
\text { Health Centre }\end{array}$ & Total & & \\
\hline 1 & 8 & 10 & 18 & 15 & 83 \\
\hline 2 & 19 & 20 & 39 & 25 & 64 \\
\hline 3 & 12 & 11 & 23 & 14 & 61 \\
\hline 4 & 7 & 13 & 20 & 11 & 55 \\
\hline 5 & 7 & 4 & 11 & 5 & 45 \\
\hline 6 & 3 & 2 & 5 & 2 & 40 \\
\hline 7 or 8 & 4 & 0 & 4 & 1 & 25 \\
\hline Total & 60 & 60 & 120 & 73 & 61 \\
\hline
\end{tabular}

Table 2 Effect of age of parents on immunisation

\begin{tabular}{|c|c|c|c|c|c|}
\hline \multirow[b]{2}{*}{ Age of mother } & \multicolumn{3}{|c|}{ No of respondents } & \multirow[b]{2}{*}{$\begin{array}{l}\text { No of fully } \\
\text { immunised children }\end{array}$} & \multirow[b]{2}{*}{$\begin{array}{l}\text { Percentage } \\
\text { fully immunised }\end{array}$} \\
\hline & Oguntolu Street & Randle Road & Total & & \\
\hline $17-19$ & 5 & 9 & 14 & 11 & 79 \\
\hline $20-22$ & 14 & 20 & 34 & 26 & 76 \\
\hline $23-25$ & 14 & 13 & 27 & 21 & 78 \\
\hline $26-28$ & 7 & 5 & 12 & 8 & 67 \\
\hline $29-31$ & 10 & 4 & 14 & 8 & 57 \\
\hline $32-36$ & 10 & 9 & 19 & 7 & 37 \\
\hline Total & 60 & 60 & 120 & 81 & 67 \\
\hline
\end{tabular}


Table 3 Effect of education of the mothers on immunisation

\begin{tabular}{|c|c|c|c|c|c|}
\hline \multirow{2}{*}{$\begin{array}{l}\text { Educational level } \\
\text { of the mother }\end{array}$} & \multicolumn{3}{|c|}{ No of respondents } & \multirow{2}{*}{$\begin{array}{l}\text { No of fully } \\
\text { immunised children }\end{array}$} & \multirow{2}{*}{$\begin{array}{l}\text { Percentage } \\
\text { fully immunised }\end{array}$} \\
\hline & Oguntolu Street & Randle Road & Total & & \\
\hline Illiterate & 17 & 8 & 27 & 9 & 33 \\
\hline $\begin{array}{l}\text { Primary school } \\
\text { completed } \\
\text { Secondary school }\end{array}$ & 24 & 31 & 55 & 37 & 67 \\
\hline $\begin{array}{l}\text { completed } \\
\text { University } \\
\text { Total }\end{array}$ & $\begin{array}{r}19 \\
0 \\
60\end{array}$ & $\begin{array}{r}20 \\
1 \\
60\end{array}$ & $\begin{array}{r}37 \\
1 \\
120\end{array}$ & $\begin{array}{r}29 \\
1 \\
76\end{array}$ & $\begin{array}{r}78 \\
100 \\
63\end{array}$ \\
\hline
\end{tabular}

AGE OF THE MOTHER

Table 2 shows the age of the mothers and the proportion of children immunised. The younger mothers attend the clinics more than the older mothers, and in the group aged $17-25$ over $75 \%$ of their children attending the clinics were fully immunised. Only $33 \%$ of the children of mothers aged 32-36 were immunised. No mother over 36 was attending either clinic at the time of the survey.

\section{EDUCATION OF THE MOTHERS}

According to table 3, the more educated the mother the higher the level of immunisation.

\section{ECONOMIC STATUS}

The occupation of the father was used to measure the social class of the family. The occupation was classified as follows:

Senior category-Permanent secretaries, doctors, engineers, lawyers, architects, university lecturers, top civil servants, accountants, executives, principals of schools, senior military, and policemen.

Intermediate category-Technical officers, pharmacists, non-university teachers, nurses, chief clerks, private and personal secretaries, etc.

Junior category-Clerks, craftsmen, junior policemen, and military men.

Semi-skilled category-Farmers, fishermen, small-scale traders, and native herbalists.

Unskilled category-Labourers, domestic workers, guards, roadside food-sellers, apprentice etc.

The two respondents in the senior category had children who were fully immunised. In the intermediate group, $79 \%$ of the children were fully immunised, in the junior category $61 \%$, and in the semi-skilled $77 \%$. The unskilled had only $57 \%$ of the children fully immunised. None of the respondent claimed to have an unemployed husband.

\section{SEX OF THE CHILD}

Of the 120 children surveyed with their mothers, 75 were boys and 45 were girls. At the Oguntolu clinic 19 of the 25 girls and 24 of the 35 boys were fully immunised while at the Randle Clinic 12 of the 20 girls and 24 of the 40 boys were fully immunised.

\section{PERCEPTION OF SEVERITY OF ILLNESS}

One of the factors that influences the mother to attend the clinics is the way she perceives the illness of her child. Table 4 shows that $36 \%$ of the mother brought their children because of fever and $31 \%$ because of diarrhoea alone or with vomiting, while $10 \%$ complained of skin diseases.

\section{SOURCES OF REFERRAL}

At the Oguntolu Clinic 53\% of the respondents were referred by the health assistants, $17 \%$ by neighbours or friends, and $13 \%$ came to the clinic on their own.

Randle Clinic does not have field health assistants, but $73 \%$ of the respondents came on the recommendation of their neighbours or friends and $27 \%$ reported on their own. The average age of the infant at first clinic attendance at the Oguntolu Clinic was 2 months while it was 8 months at the Randle Clinic.

\section{FAILURE TO KEEP CLINIC APPOINTMENTS}

Table 5 shows why some respondents missed more than one clinic appointment. In both clinics the most frequent reason was because the mother or father

Table 4 Perception of severity of illness

\begin{tabular}{lllll}
\hline & \multicolumn{2}{l}{ No of respondents } & & \\
\cline { 2 - 5 } $\begin{array}{llll}\text { Illness } \\
\text { (symptoms) }\end{array}$ & $\begin{array}{l}\text { Oguntolu } \\
\text { Street }\end{array}$ & $\begin{array}{l}\text { Randle } \\
\text { Road }\end{array}$ & Total & $\begin{array}{l}\text { Percentage } \\
\text { of total }\end{array}$ \\
\hline Diarrhoea & 14 & 11 & 25 & 21 \\
Fever & 30 & 13 & 43 & 36 \\
Skin disease & 8 & 4 & 12 & 10 \\
Cough & 10 & 15 & 25 & 21 \\
\hline
\end{tabular}

Table 5 Reason for missed visits

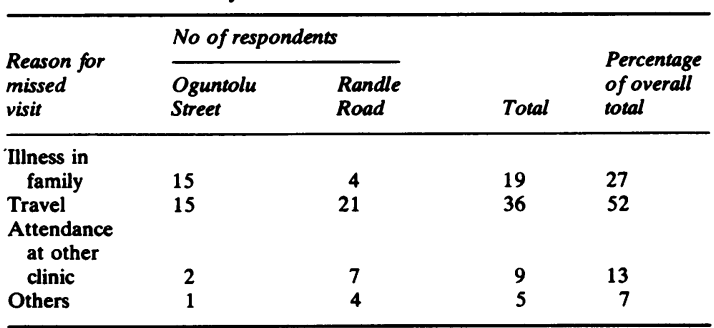


Table 6 Predictive model for identification of high need/low users and low need/high users

\begin{tabular}{|c|c|c|}
\hline Indicator & High needllow users & Low need/high users \\
\hline $\begin{array}{l}\text { No of children } \\
\text { Age of child at }\end{array}$ & Many (4 or more) & Few (2 or less) \\
\hline $\begin{array}{l}\text { attendance } \\
\text { Father's whereabouts }\end{array}$ & $\begin{array}{l}\text { Over } 6 \text { months } \\
\text { Separated from } \\
\text { family }\end{array}$ & $\begin{array}{l}2 \text { months or earlier } \\
\text { Lives with family }\end{array}$ \\
\hline $\begin{array}{l}\text { Children's age } \\
\text { Mother's age } \\
\text { Mother's education }\end{array}$ & $\begin{array}{l}\text { Includes schoolage } \\
30 \text { s or older } \\
\text { No formal education }\end{array}$ & $\begin{array}{l}\text { Mostly preschool age } \\
\text { Early } 20 \text { s } \\
\text { Secondary school } \\
\text { completed }\end{array}$ \\
\hline Father's employment & $\begin{array}{l}\text { Unskilled or } \\
\text { unemployed }\end{array}$ & Senior category \\
\hline Mobility & Frequent travels & Infrequent travels \\
\hline
\end{tabular}

were away from Lagos at the time of the appointment. This together with frequent changes of address may indicate a measure of family instability. Some of the respondent did not keep the appointment because the child was "ill" and had to be taken to another clinic or hospital.

\section{Discussion}

It is important to have a clear understanding of the factors that may influence the use of a new social amenity such as the primary health care clinics. The effects of some socioeconomic, psychological, and demographic factors on the attendance of children and the use of the children primary health care clinics were examined in this study. Although the specific findings apply primarily to the Oguntolu and Randle Road primary health care centres, the same issues may be relevant to other clinics throughout Nigeria and, indeed, other developing countries. It may be assumed that any human settlement will have a wide range of family characteristics, problems, and resource use patterns. Objectives and systematic knowledge about such variations are prerequisites to the more effective delivery of care in any neighbourhood, be it poor or rich. ${ }^{1}$

In this study the size of the family has a direct effect on the attendance at the clinics, the mothers with smaller families had more immunised children than the mothers with large families. This finding agrees with the previous one in which it was noted that the frequency with which an individual mother attends the infant welfare clinics varies with the size of the family but is more frequent during the first year of life and with first children whose mothers are therefore less experienced, ${ }^{5}$ but also have more time to spend on fewer children.

The younger the mother, the more likely it is that her child will be brought to the clinic for care. Of the respondents studied, the mothers aged between 17 and 19 had $78 \%$ of their children attending fully immunised while the mothers over 30 had about $33 \%$ of their children attending who were fully immunised. In between these age limits the trend follows a consistent pattern. This is similar to the findings of Slessinger, ${ }^{8}$ who concluded that the use of welfare services at the infant welfare clinics is affected by the age of mothers, with the younger ones reporting greater use of preventive services. A boy has a better chance of being brought to the clinics than a girl, perhaps due to the preference for boys among the various cultural groups in the developing countries.

The educational level of the parents has a direct effect on the frequency of attendance at the infant welfare clinics and hence on the level of immunisation of the children. The illiterates were found to have fewer immunised children than those who had completed primary school. Those who had completed secondary school had more immunised children than those with primary school education. As has also been noted there was a direct relationship between education and the use of preventive services. $^{7}$

In our study the family income does not seem to have a clear-cut effect on the attendance at the clinics. Those in the higher income groups, however appear to attend the clinics more often than those in the lower income groups.

The clinics studied were free clinics. When cost and other economic barriers are removed from access to medical care, and valuable service is offered, differential use of medical service by social class disappears. Whenever cost is a factor, however, use of preventive services shows strong relation to socioeconomic status. ${ }^{8}$ Health care ranks low among the priorities of the poor, being overshadowed by employment, finance, housing, safety, and other daily concerns. ${ }^{\text {-11 }}$

The perception of disease is a factor in the attendance of the mothers at the clinics with their sick children. Fever was the major factor in this effect while skin disease accounted for the least. This finding confirms the conclusions that perceptions of disease susceptibility and severity of illness influence immunisation decisional process. ${ }^{12}$

The method of referring the respondents to the clinics appears to have a direct relationship with the attendance at the clinics. At the Oguntolu Street Clinic with family health workers the average age of the children on the first day of attendance at the clinic was far lower than at the Randle Road Health Centre, which suggests that family health workers encourage early and regular attendance at clinics.

The attendance of children at the primary health care centre is affected by some social, economic, psychological, and demographic factors. This study has confirmed the distinctive characteristics of the immunised subpopulation. 
This work elucidates the impact of the family health assistants who are found to make for early reporting at the clinics and also regular attendance. $\mathbf{A}$ model for classifying families according to service need and receptivity is proposed in table 6 . Further research, however, needs to be done to validate and refine the proposed model. We hope that such a model will facilitate the formulation of more realistic primary health care programme priorities and policies.

\section{References}

${ }^{1}$ Leopold EA. Whom do we reach? A study of health care utilization. Pediatrics 1974; 53: 341-8.

${ }^{2}$ Bellin SS, Geiger HJ. Actual public acceptance of the neighbourhood health centre by the urban poor. JAMA 1970; 214: 2147-53.

${ }^{3}$ Bergner L, Yerby A. Low income and barriers to use of health services. $N$ Engl J Med 1968; 278: 341-3.
${ }^{4}$ Albert J, Heagarty M, Robertson L, et al. Effective use of pediatric care-utilization of health resources. Am J Dis Child 1968; 116: 529.

5 Jolly $\mathrm{H}$. The follow-up clinic-diseases of children. London: Blackwell, 1973: 78.

${ }^{6}$ Slessinger DP. Effects of social characteristics on the utilization of preventive medical services in contrasting health programme. Medical Care, 1976; 14: 392-404.

${ }^{7}$ Mechanic D. Sociology and public health, perspectives for application. Am J Public Health 1972; 62: 146-9.

${ }^{8} \mathrm{Kirscht}$ JP. Public response to various written appeals to participation in health screening. Public Health Rep 1975; 90: 539-43.

${ }^{9}$ Koss J, Antonovsky A, Zola I, eds. Poverty and health-a sociological analysis. Cambridge, Mass: Harvard University Press, 1969.

${ }^{10}$ Rainwater $\mathrm{L}$. The lower class: health illness and medical institutions. In: Deutscher I, Thompson E, eds. Among the people encounters with the poor. New York: Basic Books, 1968.

${ }^{11}$ Strauss AL. Medical organization, medical care and lower income groups. Soc Sci Med 1969; 3: 143-6.

${ }^{12}$ Markland DA. An investigation of sociopsychological factors affecting infant immunisation. Am J Public Health 1976; 612: 168-70. 